Wilfrid Laurier University

Scholars Commons @ Laurier

8-1-1991

\title{
The National Question in Canada: Quebec
}

Rhoda E. Howard-Hassmann

Wilfrid Laurier University, hassmann@wlu.ca

Follow this and additional works at: https://scholars.wlu.ca/poli_faculty

\section{Recommended Citation}

Howard-Hassmann, Rhoda E., "The National Question in Canada: Quebec" (1991). Political Science Faculty Publications. 22.

https://scholars.wlu.ca/poli_faculty/22

This Article is brought to you for free and open access by the Political Science at Scholars Commons @ Laurier. It has been accepted for inclusion in Political Science Faculty Publications by an authorized administrator of Scholars Commons@ Laurier. For more information, please contact scholarscommons@wlu.ca. 


\title{
The National Question in Canada: Quebec
}

\author{
Rhoda E. Howard*
}

The contemporary conflict between the province of Quebec and the federal government in Canada has recently been a focus of international attention. Quebec is inhabited by a majority group of French-speakers whose ancestry is rooted in Quebec, whose historical religion is Roman Catholicism, and who are known collectively (in French) as "Quebecois." The conflict involves Quebec's claim to special recognition as a separate entity-a nation or a "distinct society" - within Canada. This claim clashes with the rights of individuals to express themselves in the official language (French or English) of their choice and also puts in doubt the idea of a national "Canadian" identity.

\section{THE QUEBECOIS AND MINORITY LANGUAGE RIGHTS}

In 1759 the British conquered New France (Quebec), inaugurating over two hundred years of struggle by the Quebecois to maintain their language and culture against the onslaught of the English.

In 1867 Canada became a country under the British North America Act. In this Act bilingualism (the use of both English and French as official languages) was applied differentially across the provinces of Canada. To protect the English elite that had settled in Quebec, the province was declared bilingual. But many French-speaking minorities in the other nine provinces lost their language.

In the province of Ontario, language was sacrificed to religion. A publicly supported Catholic school system was established, but instruction was in English only. In the Western province of Manitoba, an 1890 law mandating

\footnotetext{
* I am most grateful to Lisa Kowalchuk for her research assistance on this paper, and to Jacques Bernier and Frederick Johnstone for their comments on an earlier draft.
} 
bilingualism was ignored in favor of English privilege until 1979. Not until 1982 was New Brunswick, one-third French-speaking, declared to be officially bilingual. All other provinces besides Quebec are unilingually English.

Until 1960 Quebec was known as a socially conservative province. In return for political cooperation, the English-speaking rulers, largely Protestant, permitted social domination by the Catholic Church, which provided French-language education and social services. Nevertheless, the English ruling elite and business class dominated the province, especially the city of Montreal, a center of commerce and banking. As late as the 1960s it was difficult for native French-speakers to obtain jobs or promotions in the business sector, and even on the factory floor Quebecois were often obliged to speak English. As late as the 1960s English-Canadian men in Quebec, who spoke only English, earned more than French-Canadian men, who spoke both French and English. In the early 1980 s Quebeckers still had comparatively low incomes and high unemployment rates compared to Ontario and the Western provinces.

Quebec underwent late modernization. The "Quiet Revolution," as it is known in Canada, occurred around 1960. The state secularized schools and social services, rates of urbanization skyrocketed, and birth rates plunged. A new university system was set up to provide a new class of educated French-speakers who could run the expanding state bureaucracy. But the newly trained French-speaking professionals still found themselves excluded from the private-sector jobs they sought, especially in the city of Montreal. This new class of educated professionals also perceived the declining birth rate as a threat, as the percentage of people living in Quebec who were Quebecois diminished and the proportion of English-speakersincluding large groups of immigrants-rose.

One result of this modernization and the concomitant rise in nationalist feeling was a short-lived period of political terrorism from about 1963 to 1970. Some 200 bombings occurred in Quebec during this period. Two people were killed in two separate incidents, and another twenty-seven were injured when the Montreal Stock Exchange was bombed. The terrorist period culminated in the kidnapping of the British Trade Commissioner and the kidnapping and murder of a Quebecois-but non-nationalist-cabinet minister in 1970.

Concurrently with these events, the Parti Quebecois, whose platform was political sovereignty for Quebec, was formed. It gained power in 1976 with 41 percent of the vote. Through its social democratic welfarist policies, the Parti Quebecois continued the expansion of the Quebec Government, providing jobs for the newly educated elite. It also began to institute reforms that would open up more jobs to French-speakers and ensure integration of immigrants into the French-speaking, rather than the English-speaking, milieu.

The chief instrument of such reform was language legislation. Bill 101, 
passed in 1977, declared French the only language of the Quebec government and courts. The bill also declared that children of immigrants, coming both from outside Canada and from other provinces, were required to attend French schools (and that French-speaking parents could no longer send their children to English schools). Finally, Bill 101 instituted a wide range of rules declaring French to be the language of the workplace, protecting any employee from demands that he or she speak English.

Requirements for the use of French in the workplace resulted in a business "scare," increasing emigration both of businesses and of private Englishspeakers from Quebec, although reports of the business exodus proved to be exaggerated and alarmist. English-speakers were guaranteed the right to have social services in their own language; individuals could request communications in English from the courts and the government; the English school system, although now circumscribed, was retained; and individuals could speak English among themselves at their place of work if all parties preferred. The intent was to protect the rights of the English as a linguistic minority within Quebec, but not to consent to the idea of Quebec as a bilingual province within a bilingual country.

In 1980 there was a referendum in Quebec on the question of sovereignty-association, a loosely defined proposal by the Parti Quebecois to revise Quebec's relationship with the rest of Canada in such a manner as to obtain political sovereignty while retaining economic association with the rest of the country. This referendum was defeated by a sixty to forty split, but the split among the ethnic Quebecois was closer to fifty-fifty. In 1984 the Parti Quebecois lost power to the provincial Liberals, who were reelected in 1988. The Liberals were a non-separatist provincial party that nevertheless had become strongly nationalist, and in any case had no choice but to maintain the policies to preserve the French language, which was perceived to be critical to Quebecois survival.

In 1982 Canada adopted a formal written Constitution including, for the first time, a formal Charter of Rights and Freedoms. But because the Constitution was adopted so soon after the sovereignty-association referendum in Quebec, and because the Parti Quebecois Government was still in power, Quebec refused to agree to it. Thus, Canada had a Constitution and a Charter of Rights and Freedoms to which all provinces except Quebec had assented. Quebec, as a consequence, felt excluded from the new Canadian constitutional order.

Further, Quebec's nationalist aspirations, and in particular its 1977 language legislation, were progressively watered down by the Supreme Court of Canada and by use of the Charter. In 1980 the Supreme Court declared invalid Bill 101's declaration that French would be the only language of the courts and the government in Quebec, and reinstituted bilingualism in that province (while seven of the nine other provinces remained officially unilingual). The 1982 Charter specifically included language rights that undercut 
Bill 101, by guaranteeing the rights of Canadians to English or French schooling anywhere in Canada that numbers warranted. This provision overrode Bill 101's requirement that English-speaking immigrants to Quebec from other Canadian provinces send their children to French schools.

Finally, in 1988, there was a dispute over the language to be used in public communications in Quebec. In order to obtain all provinces' (except Quebec's) assent to the new Constitution, the federal government had agreed in 1981 to include a special clause known as the "notwithstanding" clause in the Charter of Rights and Freedoms. Article 33(1) permits any province to pass a law notwithstanding (i.e., contravening) certain Charter provisions for a renewable period of five years, so that a province can in effect override a section of the Charter in perpetuity.

In 1988 the Supreme Court of Canada overturned Bill 101's ban on public signs in any language other than French. The Court ruled that the linguistic rights of French-speakers could be protected by less drastic measures, such as having public signs in which the French lettering was larger than that of other languages. Immediately, the Liberal Government of Quebec invoked the "notwithstanding" clause. As of this writing (late 1990) all nonFrench-language outdoor advertising is banned in Quebec. This measure is now symbolic of the entire struggle for an independent French-speaking nation in Quebec.

The sign law issue caused a great deal of concern in Quebec and the rest of Canada. On the one hand, until very recently French-speakers suffered economic, political, and social discrimination in Quebec, and their very survival as a people may well have been at stake. The collective dignity of the Quebecois, it can well be argued, depends in part on their survival as a cohesive group with a binding culture, language, and religious heritage with which all Quebecois can identify. Thus, some think that the sign law is a small price for non-French-speakers to pay for the need to preserve Quebecois culture. Many Quebecois fear that the federal erosion of Bill 101 will gradually undermine other of the bill's important provisions, such as the stipulation that French is the official language of both public and private workplaces.

On the other hand, minority language rights are protected in both the International Bill of Rights and in the Canadian Constitution. The Englishspeakers living in Quebec also have a constitutional right to protection of their own language; indeed, under Constitutional provisions for multiculturalism it can even be argued that there should be protection of the right of any minority group to advertise in its own language. Many English-speakers think that the sign law is the "thin edge of the wedge" and will result in further erosion of the rights of non-French-speaking individuals to communicate in their own language.

One way out of this problem is to note that no serious attack on the human rights of non-French-speakers seems likely to emerge in practice from 
the Quebec sign law. English-speakers still have their own schools and receive provincial government services in English. No one is being jailed for speaking English. Nor is it likely that such abuses of rights will occur in the future. The project of preserving Quebecois language and culture does not include a political project to rid the province of all non-French minorities.

\section{THE MEECH LAKE ACCORD}

During the first half of 1990 Canada engaged in a very serious debate over the Meech Lake Accord, the purpose of which was to make some constitutional changes that would enable Quebec to add its signature to the 1982 Constitution and Charter of Rights and Freedoms. In 1987 the Quebec Liberal Government specified five conditions for "re-entry," as it were, into Canada, the most important of which was the explicit recognition of Quebec as a "distinct society." The original agreement was signed in 1987 by the Prime Minister of Canada and all ten provincial Premiers. Subsequently, three successor provincial Premiers revoked their provinces' agreements, and the Accord was defeated when the deadline for official ratification on 23 June 1990 expired.

The Meech Lake Accord raised fundamental questions about the nature of Canadian society and the place of the Quebecois nation within Canada, if it chooses to remain.

First among these questions is whether Canada is to be a bilingual country or a federation of unilingual provinces, loosely allied by a central government capable of communicating with each province in its own language. When Liberal Prime Minister Pierre Elliott Trudeau took power in 1968, at the height of Quebecois nationalism, he introduced the Official Languages Act, which declared Canada a bilingual country and guaranteed federal services in both languages.

However, Quebec's Bill 101 put it firmly on the path of official French unilingualism, with democratic accommodation made for English Quebeckers as a historic linguistic minority but not as one of the two founding nations of Canada with special linguistic rights as a consequence. Immigrants to Quebec no longer had the right to choose to send their children to French or English schools; rather, they had to attend French schools. And Frenchspeaking Quebeckers could no longer send their children to English schools, as many had done in the past in order to prepare their children for life in the wider Canadian/North American society. Further, while no one could graduate from any high school (French or English) without a certificate of competence in the French language, French schools were not obliged to provide any English-language training at all, and indeed, had to seek permission from the provincial Ministry of Education should they wish to do so. 
For many Quebecois, a loose federation of a unilingually French Quebec with nine unilingually English provinces under a decentralized and weakened federal umbrella is infinitely preferable to bilingualism within Quebec itself. This view of Quebec sacrifices its ethnic ties with non-Quebecois French-speakers in other provinces to a national claim to sovereignty as a territory. The idea of a loose federation of unilingual provinces finds favor among many English-speaking Canadians outside Quebec as well. For example, many Westerners would gladly give up English-speakers' rights in Quebec for English unilingualism elsewhere, especially when decentralization would also weaken Ottawa and strengthen the provinces.

The Meech Lake Accord also raised the issue of whether Canada is a bilingual/bicultural or a multicultural community. In 1978, in recognition of the many waves of immigration that had brought people of diverse origins to Canada, the federal government declared Canada to be a multicultural society. This policy was further entrenched in the 1982 Charter of Rights and Freedoms, whose Clause 27 refers to "the preservation and enhancement of the multicultural heritage of Canadians." In 1988 the Multiculturalism Act was passed. Its purpose is to encourage activities that help the various ethnic minorities preserve their culture, to promote racial tolerance and understanding.

For the non-British, non-French ethnic minorities (excluding aboriginals or "Indians") who constitute about 23.5 percent of the population of Canada, the Meech Lake Accord appeared to undermine multiculturalism. It was feared that the definition of Quebec as a distinct society would be used to override the language rights enshrined in the 1982 Constitution. For example, Quebec could use the "distinct society" clause to reinstate the losses Bill 101 sustained regarding official French unilingualism. Under the Meech Lake Accord Quebec would also have been entitled to control at least 25 percent, and up to 30 percent, of Canada's immigration in order to make sure that the proportion of French-speakers in Quebec was sustained. The "multicultural communities" feared that this would mean fewer immigrants to Canada from their own homelands.

Thus the 1990 Meech Lake debate reopened the national question in Canada.

\section{IMPLICATIONS FOR NATIONAL IDENTITY}

In the case of Quebec, pursuit of a collective national identity has possibly disturbing implications for the future. As long as the Quebecois community was a relatively closed society, the definition of membership was easy. Those who spoke French were also Quebecois-Catholics of Quebecois ancestry. Indeed, until the mid-1970s non-Catholic French-speakers (e.g., Jewish immigrants from Morocco) were required to attend English Protestant schools. 
As of the late 1970s, Quebec encouraged increased immigration of French-speakers from, for example, Vietnam and Haiti. But by the late 1980s, some Quebecois began to question the multi-ethnic nature of French-speaking society. In late 1989 a proposal was made to survey parents of children in the Montreal Catholic school system to ascertain whether they wished to have culturally Quebecois children separated from ethnically non-Quebecois French-speakers. The proposal generated much debate before it was abandoned. In early 1990 the issue surfaced again in a new form when it became evident that many non-Quebecois children in French schools preferred to communicate among themselves in English in the corridors and on the playgrounds. A policy of banning English as a language of communication anywhere in French schools was proposed, but it was rejected on the advice of the Quebec Human Rights Commission.

The collectivist element in Quebecois culture, with its strong emphasis on the indigenous ethnic community, could possibly return the province to the conservative, ethnically exclusivist attitude that dominated politics in the decades before 1960. The danger in any granting of group rights is the question of who, in the event of conflict, takes precedence: the group or the individual. In invoking the notwithstanding clause regarding the language of signs in Quebec, the current Quebec Government has suggested that the dignity of the group takes precedence over the linguistic rights of minority individuals.

The assertion of Quebec's need to be recognized as a distinct society is partly based on historical grounds that raise the interesting question of inter-generational transfers of responsibility. Should individual Englishspeakers in 1991 be required to give up linguistic rights because other English-speakers (not even, in many cases, their ancestors) kept the Quebecois in a state of economic subordination until about 1960? This also raises the question of history versus social change. Canada in 1990, unlike Canada in 1763 or 1867, is multi-ethnic. Many members of the non-English, non-French minorities feel that the concept of two founding nations relegates them to a permanent lesser status. The most serious ethnic issues, it could well be argued, are no longer French-English. The federal government is officially bilingual, the Official Languages Act ostensibly protects English and French minorities in the various provinces (though French minority rights are still extremely weak), and the French language is firmly (and constitutionally) entrenched in Quebec. Meanwhile, the aboriginal rights of native Canadians flounder and the "visible minorities" (Canadians of non-European descent) suffer discrimination in both English and in French Canada.

Thus, the "distinct society" debate pinpoints the key national question in Canada for the 1990s; namely, how national communities are defined and redefined. In order to assert their rights as a distinct "society," the Quebecois define themselves territorially. In making this claim, those Quebecois who favor being declared a distinct society reject the identity of 
Canadian as misleading and irrelevant, if not oppressive, given the long history of effective English unilingualism outside Quebec. Canadian federalists, on the other hand, seek to establish a Canadian identity that accommodates-indeed celebrates-bilingualism as an identifying characteristic of what it means to be a Canadian. The farcical nature of this celebration, given the long history of subordination of the French, is not lost on the Quebecois. It appears that Quebec and Canada remain "two solitudes" that a genuinely national Canadian identity is impossible. 